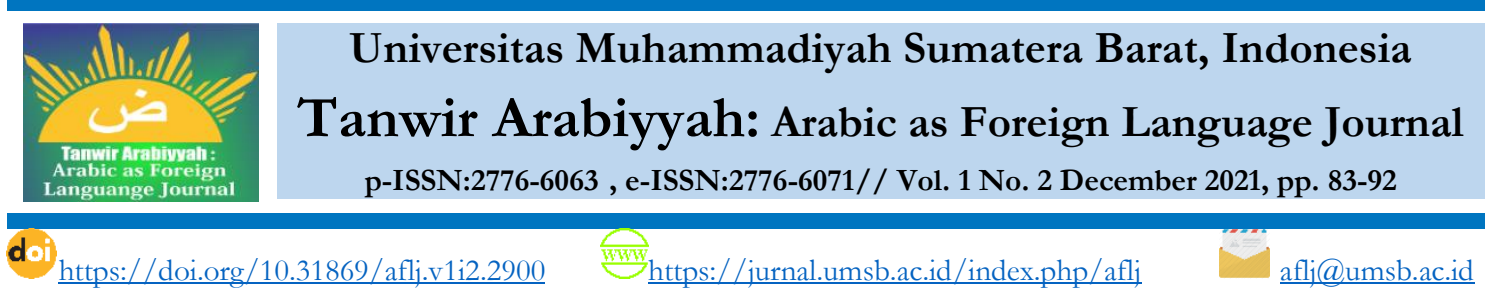

\title{
Learning Arabic for Beginners: Role-Based Small Group Discussion Cooperative Learning
}

\author{
${ }^{*}$ Hikmah Maulani ${ }^{\mathrm{a}}$, Ahmad Faqih ${ }^{\mathrm{b}}$, \\ ${ }^{\mathrm{a}, \mathrm{b}}$ Universitas Putra Indonesia \\ *ahikmahmaulani@upi.edu \\ bahmadfaqih@student.upi.edu
}

\section{ARTICLE INFO}

Article History:

Received: 29-09-2021

Revised: 05-11-2021

Accepted: 01-12-2021

Published: 10-12-2021

*Corresponding Author:

Keyword

\section{ABSTRACT}

This study examines the innovation of learning strategies through Cooperative Learning by using Role-based Small Group Discussion. The purpose of this study is to reveal indicators that influence the success of learning through cooperative learning using Role-based Small Group Discussion. This study uses a qualitative method with the implementation of structured interviews and questionnaires, the use of this data collection method is carried out to reveal the views of the participants honestly. Respondents who became participants were students who came from public schools without any experience in learning Arabic. The results obtained were found indicators in the use of Role-based Small Group Discussion, namely attitudes, abilities, and usefulness of the method.

Arabic; Cooperative Learning; Role-based Small Group Discussion

Copyright (C) 2021, Hikmah Maulani, Ahmad Faqih

This is an open access article under the CC-BY-SA license

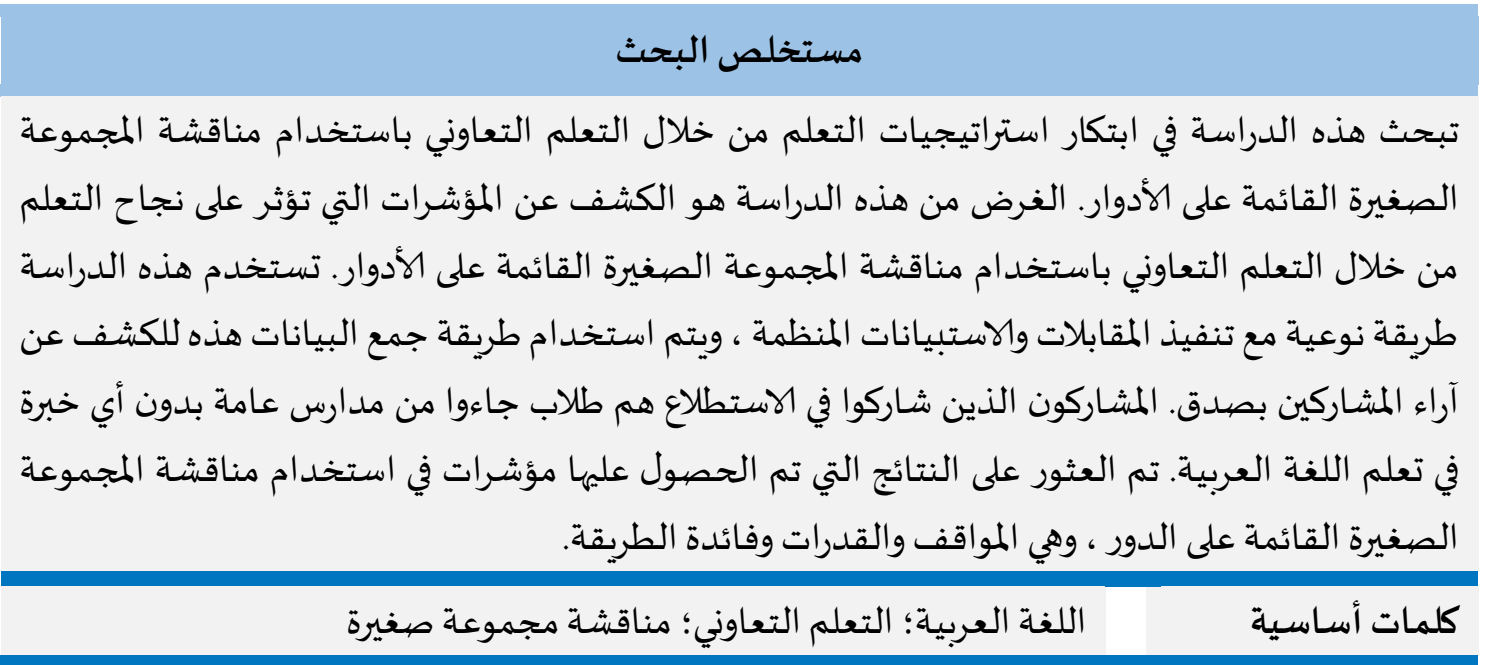




\section{INTRODUCTION}

Language learning at the initial level is an activity to equip students from the beginning on an ongoing basis so that students have discipline in thinking and speaking. In essence, learning discipline in thinking is very closely related to the development of logical aspects and language discipline refers to the development of linguistic aspects (Zulkarnaini, 2011). And language skills consist of four components, namely skills listening skills, speaking skills, reading skills and skills write. A person's language reflects his thoughts, on writing skills. Having a goal can express one's thoughts more clearly by means of indirect communication (Anggraeni \& Investigation, 2014). Based on this statement, strengthening for learning at the beginner level needs more attention, especially in the selection of strategies or learning methods.

So far, the learning process in the classroom tends to use direct learning or teachercentered learning. Direct learning is always dominated by the teacher so that the teacher becomes the main actor in learning. Direct learning does not provide space for students to communicate their ideas so that students become passive in learning (Verawati, et al., 2019).

Today, the use of Role-Base Group Discussion is considered as a learning strategy. There are indicators that are considered in the use of Role-Base Group Discussion, there are at least three dimensions of student engagement: behavioral engagement, cognitive engagement, and emotional engagement (Xu et al., 2020). Role-Base Group Discussion is a Cooperative Learning activity involving the participation of students along with lecturers and their peers. A lot of research on cooperative learning has been done (Adeyemi; 2008, Lina Ali; 2011, Azizinezhad et al.; 2013) that students exposed to cooperative learning strategy performed better than their counterparts in the other groups. The results of the study also indicated that the effect of teaching strategies was gender sensitive. Discussion or Conclusion. The findings of the study are highly significant and relevant. These results have implications for curriculum planning, teacher training and retraining programme and classroom practice.

Other successes regarding the use of cooperative learning are also noted (Lara \& Repáraz; 2007, Parveen \& Batool; 2012, Ajaja \& Eravwoke; 2011) how the adoption of cooperative learning as an instructional strategy for teaching Integrated Science influences students' achievement and attitude towards studies. Their assertion through the research carried out convinces the success and usefulness of cooperative learning as a learning strategy, in this case as explained earlier that language learning at the beginner level is emphasized requiring special attention as a foundation for learning at the next level, the researchers assess the use of cooperative learning as an alternative learning strategy that can be done in research conducted by researchers.

The closest research conducted regarding innovation in this strategy has been carried out (Chan, 2020) Although exploratory talk between teachers and students and amongst students can promote positive learning experiences and cognitive development, it is the former that has dominated much of contemporary classroom discourse, (LiebechLien, 2021) The pedagogical model cooperative learning (CL) has generated extensive research documenting its benefits for students' learning, (Peña-Ayala, 2021) At present 21st century education boosts situated teaching approaches, meaningful learning habits, and experiential use of new technology, all of which enable learners to acquire domain knowledge and develop skills during seamless scholar labors, (Heinimäki et al., 2021) During collaborative learning, students tend to spontaneously enact different participatory 
roles that may significantly affect collaborative learning processes. Only few empirical studies to date have investigated groups as systems based on emerging roles and role profiles of the participating students, and how emerging role profile configurations affect achievement. This exploration of students' self-adopted roles investigated the relationship between role profile configurations and achievement.

Based on this research, the position of this research is on the cognitive development of students who are novice Arabic learners. Furthermore, the purpose of this study is to reveal indicators that influence the development of Arabic learning for beginner students through a cooperative learning approach using a role-based small group discussion.

\section{METHOD}

This study uses a qualitative approach using a structured interview method. Interviews were conducted to explore and obtain information with honest assessments from participants. In qualitative research, the instrument or research tool is the researcher himself. Therefore, the researcher as an instrument must also be "validated" how far qualitative researchers are ready to carry out research which then goes into the field. Validation of researchers as instruments includes validation of understanding qualitative research methods, mastery of insight into the field under study, readiness of researchers to enter research objects, both academically and logistically.

Individual respondents who became participants in this study were participants of the Lisan Arab learners, which is a learning program specifically for novice students who are learning Arabic which is managed by the Ministry of Arabic Language Education, Universitas Pendidikan Indonesia. The number of participants is 20 students. The selection of respondents using non-probability sampling is new students who come from a learning experience background with minimal knowledge of Arabic.

Table 1. Participant Demographics

\begin{tabular}{ll}
\hline Characteristics & $N$ \\
\hline Male & 4 \\
Female & 16 \\
Experience & \\
$\quad$ Public schools & 15 \\
$\quad$ Madrasah & 3 \\
$\quad$ Others & 2 \\
\hline
\end{tabular}

\section{Data Collection Technique}

Data collection techniques carried out by researchers in this study, including:

1. Observing consciously and recording details of the object under study in natural conditions. 2) Analytical notes against previous notes (make notes margin, underline, color). 3) Rewrite the results of observations in the form of an estimate of the respondent's behavior (notes + answers + other people's opinions). 4) Presenting and writing in the final report (findings).

2. Interviews conducted by researchers are in-depth interviews with the aim of exploring information holistically and clearly from informants

3. Documentation carried out by researchers is by looking at, analyzing related documents that can complement research data. The document is in the form of writing or pictures 
such as teacher evaluation notes, curriculum archives, and recording tools to view learning activities

In addition to interviews, this study uses a survey through a questionnaire. The results of the questionnaire survey give judgment on the results of the interviews conducted. The psychometric scale was used in the study as a step in analyzing data from the questionnaire obtained using a Likert scale.

\section{Data Processing}

Data analysis was carried out through several stages, namely: Data reduction: In data reduction, the researcher discusses with friends or other people who are considered experts. Through the discussion, the researcher's insight will develop, so that it can reduce data that has significant findings and theory development value. Data display: The display of data used by researchers is to present data with descriptive and narrative text descriptions. Verification: Researchers verify as a validation of data findings in the field. As explained that the third step in qualitative data analysis according to Miles Huberman is drawing conclusions and verification. The initial conclusions put forward are still temporary, and will change if no strong evidence is found to support the next stage of data collection. However, if the conclusions raised at an early stage are supported by valid and consistent evidence when the researcher returns to the field to collect data, then the conclusions put forward are credible conclusions.

\section{RESULTS \& DISCUSSION}

The success of learning is largely determined by the models and learning methods designed by the teacher. Basically, teachers can use any learning model in carrying out teaching and learning activities. But the most important thing is that teachers must have careful consideration when using certain learning models. Of course, using these learning models there are expected achievements (Sulaiman, 2014).

Method variations have been carried out from time to time in line with the needs of the global community, so that affect the learning process in the classroom. However, the lack of studies strategies and methods in growing the current creative thinking process encourage more in-depth study of the topic. It aims to improve critical and creative thinking skills among students (Sulaiman, 2014). In learning, a teacher must have a vision and goals that he wants to achieve achieved in students. The vision and objectives must be conceptualized as follows: basis for choosing a suitable, effective and practical learning model. In conceptualizing a vision and goals must take into account environmental conditions, needs and student character. A learning model that fits the conditions and world of the participants students can encourage interest for students and can also produce goals maximum learning (Sulaiman, 2014).

Cooperative learning is one of the methods or learning models that can be used by teachers. In other words, cooperative learning is a teaching process in which students are taught (conditioned) to be able to work into small groups and the group is heterogeneous and by mutual assistance between students with one another in learning the material. the subject matter provided. cooperative learning model is a method, model or form of learning that focuses on the process or activity of working together in carrying out learning activities with small heterogeneous groups in order to get maximum learning conditions in order to achieve these learning objectives.

Cooperative Learning is a strategy teaching designed to educate students in working 
in groups and interaction between students. Cooperative Learning learning methods can: (a) teach students to trust the lecturers; (b) thinking ability; (c) seek information from other sources and learn from other students; (d) push students to express their ideas verbally and compare them with ideas her friend; (e) helping students to learn to respect each other smart and students who are less and can accept these differences. So that able to provide solutions for creating dynamic web sites, knowing web technology latest, able to release the web that has been created (Zainal \& Maryam, 2020).

First, the researchers conducted structured interviews with students and conducted a verbatim from the results of these interviews by analyzing the supporting factors that became the literature to obtain findings related to beginner learning using the Role-Based Small Group Discussion learning approach strategy, then identifying the findings.

Table 2. Participant Interview Analysis Draft

\begin{tabular}{lll}
\hline Participant & \multicolumn{1}{c}{ Coding } & \multicolumn{1}{c}{ Indicator Data } \\
\hline Ism \#1 & At first I was inferior (attitude), but with the & Attitude in the preparation \\
learning that was carried out through group of group discussions \\
discussions with a small scale of members, \\
also guided slowly by the teacher, thank \\
God I felt helped. So far I can catch up in \\
class (Usefulness) \\
Shn \#8 we with the teacher treating us equally Benefits of using Role- \\
because we are both beginners, as well as Based Small Group \\
his personal approach, this raises the spirit. Discussion \\
The practical work done is also relevant to \\
our abilities, but in the end at least we can \\
catch up in class (usefulness)
\end{tabular}

After that, the researcher analyzed the results of the questionnaires that had been filled in on the participants' willingness. The results of this questionnaire will be identified which will then strengthen the findings so that more in-depth data analysis can be carried out.

Table 3. Description of Questionnaire Results

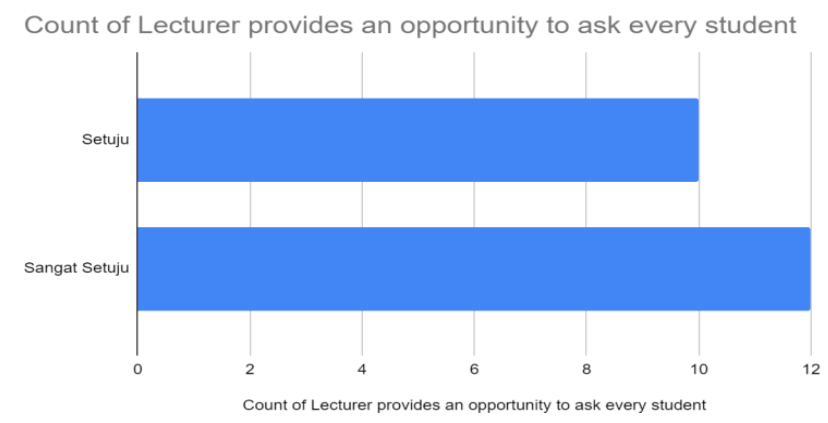




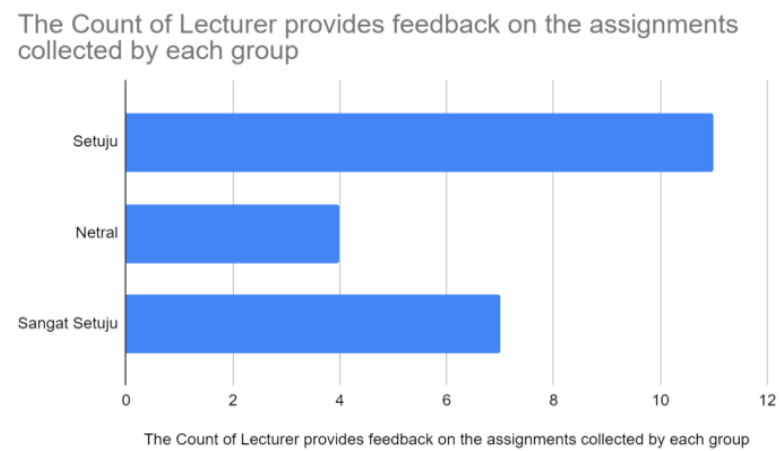

By comparing the results of the identification of the results of interviews and questionnaires, we can present the findings of this study, namely several perceptions of Role-based Group discussion, namely through the conclusions of indicators: student attitudes, student abilities, the usefulness of Role-based Group discussion strategies.

\section{Students' Attitudes}

Concept of Cooperative Learning :Cooperative learning involves students working together in small groups to accomplish shared goals. One can see that several definitions of cooperative learning have been formulated. According to them, cooperative learning is an instruction that involves students working in teams to accomplish a common goal.

Although exploratory talk between teachers and students and amongst students can promote positive learning experiences and cognitive development, it is the former that has dominated much of contemporary classroom discourse. Research over the past four decades has not provided a convincing response to whether some modes of talk may be more beneficial, and in what order (Chan, 2020).

Attitude formation that are appropriate for students will be a trigger for motivation for them to improve their effort and perseverance to learn in order to be successful. Therefore attitude is wrong one factor that needs to be considered and considered to improve the learning process teach in class. In language learning, language attitudes have an influence on students' learning motivation. Students who have a positive language attitude have a tendency to succeed compared to those who have negative.

Attitudes that refer to emotions/feelings are an emotional evaluation or reaction (the degree of liking or disliking associated with object being addressed). This can apply to, for example, feelings of liking or disliking the learner towards the speaker of the target language is an expression of his attitude towards the speaker that language. The second component, cognition, refers to what the learner knows about the object being addressed. What he knows doesn't necessarily have to be fact or truth, but what he believes can be considered cognition. For example, students may think that English speakers are poor and uneducated. In addition, the learner's knowledge of the basics of language learning can affect attitudes and behavior towards the language. The third component of attitude, behavior, related to intentions or actions related to the object of attitude. As For example, will the learner try to imitate the way native speakers speak, or will the learner do you want to continue learning? (Sudirman \& Huzairin, 2017).

Language attitude is a combination of attitudes, orientations and interests. Part The first of language attitudes, namely attitude, is used to find out what is thought, what is what is known and what the learner believes about the object being addressed. In relation What we want to know is the attitude of the learner towards native Arabic speakers, Arabic 
courses/classes and Arabic teachers. The second part is orientation. By referring to the third component of attitude as described above, then orientation refers to the reason for learning the target language. Orientation is divided into orientation integrative and instrumental orientation. The last part is interest, which is aimed at knowing the emotional reaction of the learner to the object being addressed. What is meant by interest here is the learner's interest in foreign languages.

\section{Student Abilities}

Language skills are the ability, skill, wealth of speech, thoughts and feelings of humans through arbitrary sound, used to cooperate, interact, and self-identify in good conversation. Understanding language skills is the extent to which an individual masters the symbols and meanings of language. Language is essentially a regular speech of human thoughts and feelings, which uses sound as a tool. Language ability is the ability, skill, wealth of speech, thoughts and feelings of humans through arbitrary sounds, used to cooperate, interact, and identify themselves in good conversation. Language skills are the ability to choose language sounds (in the form of words, sentences, stresses, and tones) appropriately and also to formulate them appropriately to convey thoughts, feelings, ideas, facts, actions, in a communication context.

Regarding the problem of learning Arabic for beginners by containing nahwu learning, this is as explained by (Abdullah, 2012) regarding the selection of materials when Arabic teaching materials for non-Arabs touch the theme of nahwu. There are things to note:

1. Don't overdo it or focus on learning nahwu

2. Learning nahwu should not be made into a discipline with special books and hours, except for higher levels.

3. Do not rely on teaching methods that give more attention and portion to grammar.

4. Learning grammar that is functional or urgent for learners in expressions and conversations.

5. The teaching of nahwu must not sacrifice other purposes of the language itself.

6. The examples given should not be separated from context or meaning, but will be more appropriate through the context of sentences in texts or writings given according to the ability of the learner, or learning in meaning that can enrich vocabulary, expressions, and can help improve language skills and proficiency.

7. Avoiding the use of nahwu terms in teaching unless it is absolutely necessary.

8. It is recommended not to give nahwu lessons unless the learner is proficient in distinguishing between sounds and pronouncing vocabulary.

9. Increase exercise

In conclusion, there are three things that can be considered in the learning process. First, learning produces changes in student behavior that are relatively permanent, meaning that the role of educators such as educators and lecturers is as agents of change. Second, students have potential and abilities which are natural seeds to be grown and developed without stopping. Thus learning to optimize self-potential so that the ideal quality is achieved. Third, the change or ideal achievement does not naturally grow linearly in line with the life process, meaning that the teaching and learning process is indeed a part of life itself, but it is specifically designed and intended to achieve the ideal conditions or qualities as mentioned above.

\section{Usefulness}

In cooperative learning students feel that they are working together to achieve one 
goal and are bound to one another. A student will not be successful unless all members of his group are also successful. Students will feel that they are part of a group that also contributes to the success of the group.

Cooperative learning will increase interaction between students. This, occurs in the event that one student will help other students to succeed as a member of the group. This mutual assistance will take place naturally because a person's failure in a group affects the group's success. To solve this problem, students who need help will get from their group of friends. The interaction that occurs in cooperative learning is in terms of exchanging ideas about the problem being studied together and Individual responsibility in group learning can be in the form of student responsibility.

In cooperative learning, in addition to being required to study the material provided, a student is required to learn how to interact with other students in the group. How students behave as group members and convey ideas in groups will require special skills. Cooperative learning will not take place without a group process. Group process occurs when group members discuss how they will best achieve their goals and make good working relationships

The findings of this study strongly support the theory put forward that cooperative learning (ŞIMSSEK et al., 2013) has a more positive effect on increasing students' academic knowledge and achievements. (Heinimäki et al., 2021) explain during collaborative learning, students tend to spontaneously enact different participatory roles that may significantly affect collaborative learning processes. Only few empirical studies to date have investigated groups as systems based on emerging roles and role profiles of the participating students, and how emerging role profile configurations affect achievement. This exploration of students' self-adopted roles investigated the relationship between role profile configurations and achievement.

However, there are notes in the process of learning Arabic in general, as explained In language learning, there are several strategies and methods used according to the level of students. That is, language learning activities at each level of education must be different, because the intelligence and skills of students are different according to their level. The learning of Arabic language skills for beginners is the foundation for the development of language skills at the next level. If students' istima skills are placed properly starting at this level, it will facilitate the development of istima at the next level, as well as the skills of kalam, qiraah, and kitabah. In other words, learning Arabic language proficiency at the beginner level is an introductory step for students to learn Arabic at the next level.

\section{CONCLUSIONS}

Based on the findings and discussions conducted in this study, it was concluded that role-based group discussions were considered significant in helping learning Arabic for beginners by considering students' attitudes, student abilities, and usefulness. The identification of the results is concluded in the outline that learning Arabic for beginners is the initial foundation, it is necessary to have the right strategy to strengthen the intended foundation, so Role-based Group discussion can be perceived as an alternative learning strategy, remembering and seeing the results of identifying the data obtained. Furthermore, this research needs to be carried out at the stage of evaluating appropriate learning for beginner Arabic learners. 


\section{BIBILIOGRAPHY}

Abdullah, A. A.-G. A. H. (2012). Menyusun Buku Ajar Bahasa Arab (S. Y. Husein (ed.)). Akademika Permata.

Ajaja, O., \& Eravwoke, O. (2011). Effects of cooperative learning strategy on junior secondary school students achievement in integrated science. Electronic Journal of Science Education, 14(1), 1-18.

Anggraeni, R. K., \& Investigation, G. (2014). Jurnal Waspada UND ARIS. 84-96.

Azizinezhad, M., Hashemi, M., \& Darvishi, S. (2013). Application of Cooperative Learning in EFL Classes to Enhance the Students' Language Learning. Procedia - Social and Behavioral Sciences, 93, 138-141. https://doi.org/10.1016/j.sbspro.2013.09.166

Chan, M. (2020). A multilevel SEM study of classroom talk on cooperative learning and academic achievement: Does cooperative scaffolding matter? International Journal of Educational Research, 101(January), 101564. https://doi.org/10.1016/j.ijer.2020.101564

Heinimäki, O. P., Volet, S., Jones, C., Laakkonen, E., \& Vauras, M. (2021). Student participatory role profiles in collaborative science learning: Relation of within-group configurations of role profiles and achievement. Learning, Culture and Social Interaction, 30(June). https://doi.org/10.1016/j.lcsi.2021.100539

Lara, S., \& Repáraz, C. (2007). Effectiveness of cooperative learning fostered by working with WebQuest. Electronic Journal of Research in Educational Psychology, 5(13), 731-756.

Liebech-Lien, B. (2021). Teacher teams - A support or a barrier to practising cooperative learning? Teaching and Teacher Education, 106, 103453. https://doi.org/10.1016/j.tate.2021.103453

Parveen, Q., \& Batool, S. (2012). Effect of cooperative learning on achievement of students in general science at secondary level. International Education Studies, 5(2), 154158. https://doi.org/10.5539/ies.v5n2p154

Peña-Ayala, A. (2021). A learning design cooperative framework to instill 21st century education. Telematics and Informatics, 62(April), 1-16. https://doi.org/10.1016/j.tele.2021.101632

ŞİMŞEK, A., YILAR, R., \& KÜÇÜK, R. (2013). the Effects of Cooperative Learning Methods on Students'Academic Achievements in Social Psychology Lessons. International Journal on New Trends in Education and Their Implications, 4(1), 5-9.

Sudirman, S., \& Huzairin, H. (2017). Sikap Bahasa Siswa SMP dan SMA terhadap Pembelajaran Bahasa Inggris di Kota Bandar Lampung. Aksara, 18(1), 241023.

Sulaiman. (2014). MODEL PEMBELAJARAN COOPERATIVE LEARNING (Suatu Analisis Psikologis Dalam Pembelajaran). Visipena Journal, 5(2), 25-35. https://doi.org/10.46244/visipena.v5i2.258

Verawati Dangus, Y., \& Jelatu, S. (2019). Model Pembelajaran Kooperatif Dengan Pendekatan Reciprocal Teaching Dan Contextual Teaching and Learning Terhadap Kemampuan Komunikasi Matematika Siswa. MaPan, 7(2), 229-248. https://doi.org/10.24252/mapan.2019v7n2a5

Xu, B., Chen, N. S., \& Chen, G. (2020). Effects of teacher role on student engagement in WeChat-Based online discussion learning. Computers and Education, 157, 103956. 
https://doi.org/10.1016/j.compedu.2020.103956

Zainal, Z., \& Maryam, S. (2020). Penerapan Model Pembelajaran Kooperatif Tipe Example Non Example Untuk Meningkatkan Hasil Belajar Matematika Siswa Kelas II SDN 79 Parepare. Journal of Mathematics Education and Science, 5(2), 2.

Zulkarnaini. (2011). Model Kooperatif Tipe Think Talk Write (TTW) Untuk Meningkatkan Kemampuan Menulis Karangan Deskripsi dan Berpikir Kritis. Jurnal.Upi.Edu, 2, 144153. 